\title{
ARTIKELEN
}

\section{Waarom is er zo weinig wetgevingsonderwijs in de universitaire rechtenopleiding?}

\author{
W.J.M. Voermans
}

\section{De judocentrische rechtenopleiding}

Even over de duim. Circa 90 procent van de rechtsvorming in Nederland verloopt via wetgeving, schat ik, en waarschijnlijk zelfs meer. Als academische rechtenopleidingen begrip over recht en rechtsvorming bij zouden willen brengen, dan zou je verwachten dat ze ook een flink deel van hun curriculum wijden aan rechtsvorming via wetgeving. Dat gebeurt echter niet. In de rechtenopleiding ${ }^{1}$ wordt juist heel weinig aandacht aan wetgeving besteed. Wat over wetgevingsprocedures en regelingsvormen in het constitutioneelrechtelijke onderwijs, een enkele keer een mastervak wetgeving of wetgevingsvraagstukken, ${ }^{2}$ maar daar blijft het dan ook wel bij. Hoe komt dat?

Een eerste oorzaak moet worden gezocht in traditie. Nederlandse rechtenopleidingen zijn van oudsher judocentrisch. Wat juristen in de dop wordt aangeleerd, is te denken als een rechter, dan wel de advocaat of officier van justitie, of zelfs de ambtenaar die moet weten wat er in het hoofd van een rechter omgaat. ${ }^{3}$ Als je weet hoe de rechter denkt, kun je op die manier dat denkproces proberen te beïnvloeden. En dat is wat de curricula van opleidingen rechtsgeleerdheid in Nederland dan ook hoofdzakelijk doen. Eerst de basisbegrippen aanbrengen, excursies plegen door de rechtsbronnen en dan - veelal aan de hand van jurisprudentie laten zien hoe een rechter in geval van een conflict (dat als gegeven wordt

1 De wo-rechtenopleiding wordt aan tien instellingen in Nederland verzorgd, te weten aan de Erasmus Universiteit Rotterdam, de Open Universiteit, de Radboud Universiteit Nijmegen, de Rijksuniversiteit Groningen, de Universiteit Leiden, de Universiteit Utrecht, de Universiteit van Amsterdam, de Universiteit van Maastricht, de Universiteit van Tilburg en de Vrije Universiteit.

2 Zie het overzicht in par. 2.

3 Wat Jan Vranken 'magistratelijkheid' noemt. In het door hem bewerkte Algemeen deel uit de Asserserie laat hij zien hoezeer de rechtswetenschap dienstbaar is aan de praktijk, waarin de rechter als rolmodel fungeert en de hele wetenschappelijke methode is afgestemd op de methode van de rechter. Zie Asser/Vranken, Algemeen deel*** 2005. 
beschouwd ${ }^{4}$ ) een feitencomplex ordent, dit voorziet van een juridische kwalificatie (ten onrechte vaak aangeduid als juridische analyse), belangen afweegt, en dan volgens een op schrift gesteld stappenritueel tot een conclusie komt. Geen objectieve conclusie op basis van een wetenschappelijke analyse, maar een wijs oordeel dat zich baseert op voor een juridisch gezelschap valide argumenten. Op de keper beschouwd zijn wij juristen een sterk op onszelf betrokken legitimatiegemeenschap. Een gemeenschap waar je pas na een juridische opleiding toegang toe krijgt.

Dat is ook gedeeltelijk de culturele verklaring waarom de juridische opleiding in Nederland, net als in tal van andere landen, zo'n bijzonder karakter heeft en waarom daarin sommige elementen, die je toch op zijn minst zou verwachten in een wetenschappelijke opleiding, geheel ontbreken. Denk bijvoorbeeld aan omgaan met 'gewone' mensen (dat wil zeggen niet-juristen), aan enige vorm van wetenschapsleer die je bijbrengt hoe je in en buiten het recht objectieve uitspraken van subjectieve kunt onderscheiden (hier en daar gebeurt dat wel over de band van rechtsfilosofie), aan het begrijpen hoe je onderzoek dat door anderen wordt ingebracht op hoofdlijnen kunt beoordelen, aan hoe beleid en wetgeving tot stand komen en wat je rol daarin kan zijn, o ja, en aan overheidsfinanciën, en alles wat daarbij hoort. Het verklaart ook gedeeltelijk waarom andere elementen in de rechtenopleiding volstrekt oververtegenwoordigd zijn. De meeste rechtsprogramma's kennen inleidingen in het strafrecht, privaatrecht en staats- en bestuursrecht in de propedeuse en dan nog een keer in de verdiepende bachelor. En daarna soms nog een keer. Vakken worden herhaald en herhaald. Nederlandse rechtenopleidingen zijn zowat mantrisch.

Hoe komt dat zo? Waar komt die cultuur vandaan? Als we verandering willen brengen in het juridische onderwijs - waar de laatste tijd vaak over wordt gepraat $^{5}$ - dan zul je minstens ook iets van het culturele element van juridisch werk, juridische opleidingen en juristen moeten begrijpen. Dan ook is eerst te begrijpen waarom in het juridische onderwijs nauwelijks aandacht wordt besteed aan de wijze waarop wetgeving tot stand komt (en dan bedoel ik niet slechts de juridische vormgeving van de wetgevingsprocedure) en wordt uitgevoerd, hoe met wetgeving wordt geïntervenieerd in markten, hoe via wetgeving getracht wordt onze samenleving te beïnvloeden, welke beperkingen dat kent, welke effecten dat heeft. $\mathrm{Al}$ is er heel veel te zeggen over de inrichting van juridische academische opleidingen in Nederland, in deze bijdrage zal ik me grotendeels beperken tot één

4 Wat me nogal eens opvalt in masteronderwijs en postacademische cursussen met een gehoor van 'gevorderde' juristen, is dat ze niet snappen wat een probleemanalyse is (bezien welk verschil er zit tussen de bestaande situatie en de - volgens een bepaald perspectief - gewenste situatie). Dat ligt niet aan mijn gehoor: dat is in het ergste geval even slim, maar tegenwoordig gelukkig meestal veel slimmer dan ik. Nee, ze hebben het element probleemanalyse nooit aangeleerd gekregen. Conflicten (zaken, twistgedingen, enz.) zijn er nu gewoon eenmaal voor de in Nederland opgeleide jurist. Dat verklaart ook goeddeels processen van juridisering, de moeizame weg van mediation in het recht en de problemen die wetgevingsjuristen hebben in de communicatie met veelal anders opgeleide beleidsambtenaren.

5 Zie o.a. M.J.A.M. Ahsmann, 'Het civiel effect biedt niet wat het pretendeert', NJB 2011, afl. 2, p. 66-69 en K. van den Bos, Kijken naar het recht (oratie Utrecht), 2014. 
vraag: hoe komt het dat er zo weinig aandacht is voor wetgevingsonderwijs in de curricula van Nederlandse academische juridische opleidingen? Waaraan ligt dat? Als je rechtenopleidingen begrijpt, kun je, denk ik, pas eerste stappen zetten in de richting van een verbetering. En die is nodig, zal ik betogen, omdat juridisch werk van karakter verandert, net als de rechtswetenschap zelf.

\section{Waar komt die judocentrische cultuur vandaan?}

Het praten over, laat staan veranderen, van juridische opleidingen is hele taaie materie. Een oproep voor meer aandacht voor de wetenschappelijke benadering van het recht, meer aandacht voor de wijze waarop recht tot stand komt (als mensenwerk van wetgevers of van rechtsvindende rechters), meer aandacht voor de wijze waarop overheden trachten te 'sturen' met normen, en andere soort nieuwlichterij, zoals me eens werd toegevoegd, stuit steevast op veel weerstand. Frustrerend af en toe, maar ook heel leerzaam. Want waar komt die weerstand nu vandaan? Er is zowat algehele overeenstemming over de analyse dat de universitaire rechtenopleiding in Nederland niet voldoet. Zo zou die te weinig aansluiten bij de togaberoepen, ${ }^{6}$ te weinig talent trekken ${ }^{7}$ en heel in het algemeen te weinig academisch zijn. ${ }^{8}$ Toch heeft dat, voor zover ik kan overzien, nog niet tot grote verandering in de juridische opleidingen geleid.

Volgens Bruinsma staat vooral het keurslijf van juridisch redeneren waarin studenten, docenten en alumni gevangen zitten, in de weg aan enige vernieuwing of verandering. ${ }^{9}$ We zijn met zijn allen een beetje gebrainwasht en lijden massaal aan een soort juridische tunnelvisie - niet langer ontvankelijk voor een open blik op de wereld, de context van het recht. ${ }^{10}$ Daarmee wordt de universitaire rechtenstudie het slechtste van twee werelden: geen academische vorming én geen beroepsopleiding. Dat mag misschien somber klinken, Bruinsma slaat wel de

6 Ahsmann 2011.

7 A. Dorresteijn, 'De rechtenopleiding opnieuw de maat genomen?', NJB 2011/406, p. 472-474.

8 Zie o.a. C.J.J.M. Stolker, Rethinking the Law School, Cambridge: Cambridge University Press 2014.

9 F. Bruinsma, 'Wetenschap of woordkunst: het werkgroeponderwijs als toets', NJB 2008, afl. 39, p. 2451-2455.

10 Zie in die zin ook M. Loth, 'Hoe raar zijn die juristen eigenlijk? Naar een pluriforme rechtswetenschap in een transnationale context', NJB 2014/1272. 
spijker op zijn kop als hij de universitaire rechtenopleiding duidt als voornamelijk een socialisatieproces. ${ }^{11}$ Dat is het zeker.

\subsection{De dubbele horde voor het wetgevingsonderwijs}

Op vier Nederlandse juridische faculteiten wordt er in enigerlei vorm onderricht gegeven. Aan de Universiteit van Amsterdam wordt in de master Staats- en Bestuursrecht een 'Wetgevingspracticum' gegeven (12 ECTS). Een groot, verplicht vak voor studenten die binnen de master het profiel staatsrecht kiezen. ${ }^{12}$ Een vak ook waarin veel aspecten van het wetgeven aan de orde komen, ook enige contextuele. ${ }^{13}$ Aan de Universiteit Leiden wordt het vak 'Wetgevingsvraagstukken'14 aan studenten van de masterprofielrichting Staats- en bestuursrecht aangeboden. Een verplicht vak, maar met een kleinere studiebelasting dan in de Amsterdamse master (5 ECTS). ${ }^{15}$ Aan de Universiteit Utrecht wordt het vak 'Wetgeving en Begroting en Uitvoering' aangeboden in de master Staats- en bestuursrecht. Weliswaar verplicht, maar met een relatief bescheiden studielast (2,5 ECTS). ${ }^{16}$ Het vak legt, afgaande op de vakomschrijving, wel een accent op sturingsvraagstukken. Bij andere opleidingen is het wetgevingsonderwijs in de vorm van een keuzevak gegoten. Aan de Vrije Universiteit wordt een groot keuzevak 'Verdiepend staats- en bestuursrecht' aangeboden (12 ECTS), waarbij het belang van de rechtsvorming door wetgeving over het voetlicht wordt gebracht en de rol die juristen (kunnen) spelen bij wetgeving. De rechtenopleiding aan de Universiteit Tilburg kent een keuzevak in de master Rechtsgeleerdheid 'Wetgeving en regulering' (6 ECTS $)^{17}$ en die van de Rijksuniversiteit Groningen een keuzevak in de Master Rechtsgeleerdheid 'Seminaar Wetgeving' (6 ECTS). ${ }^{18}$ Niet uit te sluiten

11 Levend bewijs vormen twee publicaties uit 2005. De een een Groningse project 'Wat maakt een goed jurist?' en de ander 'De droomjurist', het liber amicorum voor Karel Kraan bij gelegenheid van de Hoofddirectie Juridische Zaken van het Ministerie van Verkeer en Waterstaat, Den Haag 2005, onder redactie van Rien den Boer e.a. Vooral in de bijdragen van het Groningse boek wordt de goede of de droomjurist niet zozeer beschreven aan de hand van vakmatige eigenschappen, maar veeleer aan de hand van een soort psychosociale kenmerken: argumenten wikkend en wegend, kritisch, integer, maatschappelijk bevlogen, dat soort dingen. In een treffende bijdrage maakt de gedeeltelijk in Frankrijk opgeleide Marguery duidelijk hoezeer ook in Frankrijk het culturele element in de juridische opleidingen een rol speelt. In essentie wordt die jurist daar ook opgeleid om andere juristen te kunnen verstaan. Zie T.P. Marguery, 'Tu seras juge, ou avocat mon fils!', in: J.G. Brouwer (red.), Wat maakt een goed jurist?, Den Haag: Boom Juridische uitgevers 2005, p. 109-113.

12 Zie <http://studiegids.uva.nl/xmlpages/page/2014-2015/zoek-opleiding/opleiding/164/96635>.

13 Er wordt gebruik gemaakt van het handboek S.E. Zijlstra e.a., Wetgeven: handboek voor de centrale en decentrale overheid, Deventer: Kluwer 2012.

14 <https://studiegids.leidenuniv.nl/courses/show/34510/wetgevingsvraagstukken>. Leidraad is het handboek van Zijlstra e.a. 2012.

15 Ook hier wordt Zijlstra's handboek uit 2012 gebruikt.

16 Zie <www.uu.nl/masters/staats-en-bestuursrecht/cursussen>.

17 Met sterk accent op contextuele benadering van wetgeving - wordt ook verzorgd voor studenten bestuurskunde, <mystudy.uvt.nl/it10.vakzicht?taal=N\&pfac=FRW\&vakcode=600331 $>$.

18 Met een sterk constitutioneelrechtelijke inslag, <www.rug.nl/ocasys/vak/show?code=RGMBE 00906>. Hier wordt als achtergrondliteratuur het handboek P.J. Boon, J.G. Brouwer \& A.E. Schilder, Regelgeving in Nederland, 4de druk, Zwolle: W.E.J. Tjeenk Willink 2005 gebruikt volgens de website, <www.rug.nl/ocasys/vak/show?code=RGMBE00906 > . 
valt dat dit overzicht niet geheel sluitend is. Zo kent bijvoorbeeld de mastervariant Staats- en bestuursrecht van de Erasmus Law School een onderzoeksproject staats- en bestuursrecht (10 ECTS), hetgeen ook met een wetgevingsproject ingevuld zou kunnen worden, en kent de Universiteit Maastricht in de masteropleiding Staats- en Bestuursrecht een blok 'Marktregulering, toezicht en decentralisatie' dat raakt aan wetgevingsvraagstukken (breed begrepen als processen die leiden tot rechtsvorming via algemeen werkende rechtsnormen), maar deze niet in de kern plaatst.

Het overzicht laat zien dat de aandacht voor wetgevingsvraagstukken op zijn minst genomen stiefmoederlijk is bedeeld in de curricula van de universitaire rechtenopleidingen (ergens tussen de 1 en 4 procent van het totale vakkenpakket $^{19}$ ), zeker tegen de achtergrond van het belang van wetgeving voor de rechtsvorming. ${ }^{20}$ Enkele vakken in de master, veel daarvan als keuzevak, de meeste met een kleine ECTS-belasting. In de bacheloropleidingen rechtsgeleerdheid is een vak regulering, regelgeving of wetgevingsvraagstukken als zodanig helemaal niet terug te vinden. Al zal, denk ik, niemand werkelijk durven ontkennen dat in een continentaal rechtsstelsel als het Nederlandse het primaat van de rechtsvorming ligt bij de wetgever, het belang ervan wordt niet gereflecteerd in de opleidingscurricula.

Is dat erg? Iedereen heeft natuurlijk wel, vanuit de achtergrond van de eigen discipline, een boodschappenlijstje met verzoeknummers die in de rechtenopleidingen gedraaid zouden moeten worden. Huurrecht, consumentenrecht en vele andere vakken die veelal ook ontbreken. En natuurlijk vinden we allemaal dat rechtstheorie of metajuridica en rechtssociologie wel/niet meer accent zouden moeten krijgen. Zulk soort discussies zijn ook van alle tijden en behoren tot de getijdenwerking van juridische opleidingen. Ik zou het graag wat anders zien, maar daar zit mijn zorg niet. De stiefmoederlijke bedeling van wetgevingsvraagstukken heeft wel een ander effect (wellicht is het ook een oorzaak), dat me meer zorgen baart. De juridische opleiding is, zoals Bruinsma laat zien, inderdaad een groot socialisatieproces, en dan nog wel eentje dat juristen ook opleidt in een té groot vertrouwen in de rechter (betrouwbaar, want jurist) en wantrouwen in rechtsvorming via wetgeving (want wordt medebepaald door niet-juristen).

19 Een gemiddelde academische rechtenopleiding kent zo'n 250 ECTS aan vakkenwaarde.

20 Er is natuurlijk wel postacademisch wetgevingsonderwijs, dat nu veelal via de Academie voor Wetgeving wordt aangeboden. Dat onderwijs is voornamelijk gericht op het aanleren van kennis en vaardigheden die een wetgevingsjurist nodig heeft. Daar valt ook veel over te vertellen, maar het is vooral opvallend dat een groot deel van het wetgevingsonderricht ook wereldwijd postacademisch is. Van Stanford University, Boston University en Tulane University (New Orleans) tot aan het William Dale Centre van het Institute for Advanced Legal Studies in Londen zijn er voorbeelden van postacademische wetgevingsopleidingen te vinden, die dan ook nog vaak via clinics worden aangeboden. Ik behandel die niet omdat die alleen een antwoord kunnen geven op methoden van wetgevingsonderwijs in heel verschillende jurisdicties. Wellicht een keer iets voor een ander artikel. 


\subsection{Opgevoed tot wantrouwen in de wetgever?}

Een fraaie illustratie van dat wantrouwen is terug te vinden in het debat dat de afgelopen jaren werd gevoerd over het legaliteitsbeginsel. In die discussie waren het uitgerekend juristen die een probleem lijken te maken van de werking van het legaliteitsbeginsel. Dat beginsel doet als norm op steeds meer terreinen waar de overheid stuurt zijn intrede, om zo de gestuurden te (kunnen) betrekken bij sturingsbeslissingen en -handelingen (in een democratische rechtsstaat kunnen namelijk volksvertegenwoordigers meepraten over de inrichting van wettelijke bases). Toch wordt de laatste jaren dat beginsel als een wat doorgeslagen en, volgens sommigen, achterhaald rechtsbeginsel ervaren. Scheltema gaf, nadat Van Ommeren in zijn proefschrift al eerder het legaliteitsbeginsel had gerelativeerd, ${ }^{21}$ daartoe in de vroege jaren negentig een aanzet, toen hij het einde van het legaliteitsbeginsel, zoals we dat nu kennen, aankondigde. ${ }^{22}$ Dat beginsel voldoet, volgens hem, allang niet meer aan zijn eigenlijke doel: het beschermen van burgers tegen onjuist overheidsoptreden. Het frustreert tegenwoordig eerder de prestaties die we van een modern bestuur verwachten, volgens Scheltema. De oplettende lezer ziet dat hier de discussie over andere functies die dat legaliteitsbeginsel ook heeft (bijvoorbeeld het betrekken van burgers bij de rechtsvorming) buiten de haken wordt geplaatst, door te spreken over het 'eigenlijke' doel van dat beginsel, en het zo te vernauwen tot een (discussie over een) strikt juridische in casu bestuursrechtelijke context (met name rechtsbescherming tegen de overheid). Andere functies van het legaliteitsbeginsel (zoals de legitimerende, politieke, prerogatieve en communicatieve functie) ${ }^{23}$ bestaan gewoonweg niet, oordeelde een latere Scheltema over een preadvies voor de NJV. ${ }^{24}$ Scheltema's inschatting uit de jaren negentig sloeg aan onder juristen, want er volgden veel

21 F.J. van Ommeren, De verplichting verankerd: de reikwijdte van het legaliteitsbeginsel en het materiele wetsbegrip (diss. Amsterdam VU), Deventer: W.E.J. Tjeenk Willink 1996.

22 M. Scheltema, 'Van rechtsbescherming naar een volwaardig bestuursrecht', NJB 1996, p. $1355-1362$.

23 Deze functies worden in de - met name buitenlandse - literatuur wel onderscheiden. Natuurlijk moeten we er daarbij wel rekening mee houden dat ons Nederlandse legaliteitsbeginsel niet dezelfde betekenis heeft als bijv. het principle of legality, het Legalitätsprinzip of le principe de légalité in andere rechtsstelsels. Zie daarover L.F.M. Besselink, F. Pennings \& S. Prechal (red.), The Eclipse of the Legality Principle in the European Union, Alphen aan den Rijn: Kluwer Law International 2011. Echter, dat maakt de buitenlandse literatuur daarmee nog niet onbruikbaar: de juridische betekenis kan dan verschillen, de functies die het beginsel vervult, zijn wel degelijk vergelijkbaar. Zie verder voor deze functies W.J.M. Voermans, 'Legaliteit als middel tot een doel', in: Controverses rondom legaliteit en legitimatie, Handelingen Nederlandse Juristen-Vereniging, jrg. 141, Deventer: Kluwer 2011, p. 12-14.

24 M. Scheltema, 'Legaliteit als middel tot een doel, bespreking preadviezen NJV 2011', NJB 2011, afl. 22, p. 1432-1436. 
meer overlijdensadvertenties over het legaliteitsbeginsel. ${ }^{25}$ En dat terwijl in de praktijk het legaliteitsbeginsel toch ontegenzeggelijk aan een opmars bezig is. De legaliteitsnorm bestrijkt een steeds groter aantal vormen van overheidssturing, denk bijvoorbeeld aan de werking van artikel 4:23 van de Algemene wet bestuursrecht, aan de ontwikkeling van de jurisprudentie op het terrein van het legaliteitsbeginsel vanaf 1973, aan het rapport Orde in de regelgeving uit 1985 en aan de daaruit voortvloeiende normen neergelegd in de Aanwijzingen voor de regelgeving en de legisprudentie van de Raad van State van de afgelopen 25 jaar.

Wonderlijk. Aan de ene kant natuurlijk goed dat de ontwikkeling van het legaliteitsbeginsel kritisch wordt gevolgd, aan de andere kant bijzonder dat de verbreding van het bereik en de betekenis ook wordt ontkend. Waarom zit het zo in de weg?

Zou dat mogelijk te maken kunnen hebben met het feit dat juristen door hun opleiding (en socialisatie) niet als vanzelf al te veel vertrouwen hebben in de wet en de afwegingen die de wetgever maakt ${ }^{26}$ Ik neem de vrijheid een flink stuk te citeren over wat ik daarover in 2011 schreef, omdat dat volgens mij nog steeds relevant is.

'De (...) wet wordt toch vaak eerder gezien als een betrekkelijk willekeurige uitkomst van politieke machinaties dan als de adequate uitdrukking van de - op rechtvaardigheidsidealen gestoelde - beginselen van het recht. Voor het vinden van wat werkelijk "recht" mag heten en de ontwikkeling daarvan vertrouwen veel van onze vakgenoten liever op de rechter, die volgens de systeemeigen logica van het recht zelf voortbouwt aan de verwezenlijking van rechtsidealen. Dat gaat het best per geval, van uitspraak naar uitspraak - zo leert de wijsheid van eeuwen - en niet via de korte baan van door niet-juristen $^{27}$ gevonden rechtsoplossingen in de vorm van algemene regels met beperkte houdbaarheidsdatum. Burkens, Kummeling, Vermeulen en Widdershoven wijzen er bijvoorbeeld op dat de wet aan legitimiteitsgehalte heeft verloren, en dat te betwijfelen valt of het huidige wetgevingsproces nog wel voldoende garanties biedt voor het rechtsgehalte van de wet. ${ }^{28}$ Dat heeft er in hun ogen mee te maken dat parlementariërs zich meer als partijvertegenwoordiger dan als volksvertegenwoordiger opstellen. Analyses die niet direct

25 Het tijdschrift Bestuurswetenschappen bracht in 2009 een serie bijdragen uit onder de titel 'Legaliteit uit de tijd'. De serie stond onder redactie van H.D. Stout en bevatte bijdragen van Stout zelf (Bestuurswetenschappen 2009/1), S. Stoter en J. Rijnsdijk (Bestuurswetenschappen 2009/2), B. Hendriks (Bestuurswetenschappen 2009/3), F.J. van Ommeren (Bestuurswetenschappen 2009/4), H.D. Stout, S. Stoter en M. de Jong (Bestuurswetenschappen 2009/5), S. Berndsen, L. Huberts en A. van Montfort (Bestuurswetenschappen 2009/6) en een slotbeschouwing door I.C. van der Vlies (Bestuurswetenschappen 2009/6).

26 Zie Voermans 2011, p. 75-78.

27 Althans niet altijd.

28 M.C. Burkens, H.R.B.M. Kummeling, B.P. Vermeulen \& R.J.G.M. Widdershoven, Beginselen van de democratische rechtsstaat: inleiding tot de grondslagen van het Nederlandse staats- en bestuursrecht, Alphen aan den Rijn: Kluwer 2006, p. 180-181. Zie in deze zin ook T. Koopmans, Courts and Political Institutions, Cambridge: Cambridge University Press 2003, p. 95-97. 
tot vertrouwen inspireren in het legitimerende vermogen van wettelijke regelingen.'29

Er is duidelijk sprake van 'juridisch ongemak met de wetgever'. ${ }^{30}$ En dat is eigenlijk wel wat bijzonder, want die wet komt, zoals we al meermalen vaststelden, bij de hedendaagse rechtsvorming en rechtspleging een centrale plek toe, zoals ook het kabinet het in de nota 'Juridisering in het openbaar bestuur' onlangs verwoordde: ${ }^{31}$

'Kern van een democratische rechtsstaat is dat de wet bij uitstek het democratisch gelegitimeerde instrument is om aan de samenleving gezaghebbend normen op te leggen en aan het bestuur taken en bevoegdheden op te dragen.'32

Als we het op de keper beschouwen nog meer dan ooit tevoren, vond ik - net als $\mathrm{nu}-$ in 2011. Wetgeving is ook het vehikel dat de rechtsvorming grotendeels legitimeert in moderne verhoudingen:

'Een wettelijke basis, de wet, legitimeert nog steeds - en misschien wel meer dan ooit - de publiekrechtelijke rechtsvorming en het overheidsoptreden dat er op is gebaseerd. Op verschillende manieren. Wettelijke normen worden niet via willekeurige meerderheidsbeslissingen vastgesteld, maar vormen het resultaat van een belangenafweging, waarbij politieke gezichtspunten naast en tegen elkaar worden afgewogen in een open forum, volgens een transparante procedure. ${ }^{33}$ Witteveen wijst er - met een verwijzing naar Waldron - op dat onenigheid en verschillen van opvatting, politieke twist, bij het tot stand komen van wetten niet als een negatief element moet worden gezien. De wet kan tegenstellingen overbruggen door verschillende elementen uit een discussie op weg er naar toe te reflecteren en afspraken na politieke strijd te internaliseren. "De wet als collectief besluit bindt alle burgers beter, indien na duidelijke en openbare beraadslaging verschillende gezichtspunten ten aanzien van te nemen besluiten zijn uitgewisseld". ${ }^{34}$ Waldron bepleit daarom ook een herwaardering van wetgeving. ${ }^{35}$ Ook Habermas onderkent dat legaliteit

29 Voermans 2011, p. 75-76.

30 Voermans 2011, p. 76.

31 E.M.H. Hirsch Ballin, 'De revitalisering van de wet als primaire rechtsbron', in: P.P.T. Bovend'Eert e.a., De staat van wetgeving: opstellen aangeboden aan prof. mr. C.A.J.M. Kortmann, Deventer: Kluwer 2009, p. 1-10.

32 Zie kabinetsstandpunt 'Juridisering in het openbaar bestuur', Kamerstukken II 1998/99, 26360, 1 , p. 5.

33 Of zoals Waldron het uitdrukt: 'The modern legislature is an assembly of representatives of the main competing views in society, and it conducts its deliberations and makes its decisions in the midst of the competition and controversy among them.' J. Waldron, Law and Disagreement, Oxford: Clarendon Press 1999, p. 23.

34 Wetenschappelijke Raad voor het Regeringsbeleid (WRR), De toekomst van de nationale rechtsstaat, Den Haag: WRR 2002, p. 238.

35 J. Waldron, The Dignity of Legislation, Cambridge: Cambridge University Press 1999. 
bij kan dragen aan de legitimiteit van het recht. ${ }^{36}$ Niet alleen omdat volksvertegenwoordigers deelnemen aan de besluitvorming (input-participatie) over wetgeving, maar ook door het openbare debat dat erover wordt gevoerd. Dat discoursprincipe - zoals hij dat noemt - is wezenlijk voor het draagvlak van het recht. ${ }^{37}$ Het recht wint aan legitimiteit door legaliteit door de openbare procedure die het doorloopt (throughput-legitimiteit zoals Scharpf dat noemt ${ }^{38}$ ) en door de wijze waarop het - probeert - een oplossing voor problemen te bieden (output-legitimiteit). Een wettelijke grondslag vragen voor alle interveniërende overheidsoptreden heeft dus belangrijke directe en indirecte legitimerende effecten voor dat optreden. 39

Het zou flauw zijn om aan het einde van deze overwegingen een quod erat demonstrandum uit te roepen en te pleiten voor meer wetgevingsonderwijs. Het gaat er juist om te laten zien dat we met de huidige inrichting van de juridische curricula blinde hoeken van eigen gelijk (via een overwaardering van rechterlijke rechtsvorming en een onderwaardering van politieke en maatschappelijke actoren in de rechtsvorming) aan het creëren zijn. En dat kan toch nooit de bedoeling zijn van een academische opleiding in het recht.

\section{Feiten en cijfers: terugloop van klassieke juridische functies}

Wie niet zo van de verheven waarden van het academische onderwijs is, die zou kunnen zeggen dat het allemaal zo'n vaart niet loopt. Rechtenopleidingen in de hele wereld werken zo. En Nederland heeft professionele rechtshulpverleners nodig. Dat hele verhaal hierboven is een aanbodgedreven verhandeling. Je moet kijken naar vraag, de noden van de praktijk. Die verklaren ook het best de huidige inrichting van de juridische opleidingen. De grootafnemers in het beroepenveld bepalen - terecht - de inrichting. Er is niet zoveel vraag naar mensen met verdiepte wetgevingskennis (hooguit 750 ambtenaren, die dat doen op rijksniveau), des te meer behoefte is er aan gerichte kennis van het burgerlijke recht en het strafrecht. Opleiding volgt beroepenveld. Maar klopt dat nog wel? De rechtenopleidingen in Nederland lijken inderdaad in een praktische behoefte te voorzien. De meeste instromende studenten willen advocaat, officier van justitie of rechter worden, dus die worden met dit menu keurig bediend. Vraag en aanbod zijn

36 Ashenden wijst erop dat Habermas in historisch perspectief goed heeft gezien dat 'the issue of legitimacy in modernity is framed in terms of the democratic genesis of legal norms'. S. Ashenden, 'Legality, Legitimacy, and the Circumstances of Sociology', in: C. Thornhill \& S. Ashenden (red.), Legality and Legitimacy: Normative and Sociological Approaches, Baden-Baden: Nomos 2010, p. 60 .

37 J. Habermas, Faktizität und Geltung, Frankfurt am Main: Suhrkamp 1992, zie m.n. p. 187-207.

38 Scharpf onderscheidt drie wijzen waarop beslissingen legitimiteit kunnen verwerven, te weten via 'input-legitimiteit' (deelnemerschap bij de beslissing), 'throughput-legitimiteit' (via een afspraak over de procedure) en 'output-legitimiteit' (overtuiging door het - heilzame - effect). F.W. Scharpf, Governing in Europe: Effective and Democratic?, Oxford: Oxford University Press 1999.

39 Voermans 2011, p. 76-77. 
vanuit dat perspectief redelijk in evenwicht. En de meeste afgestudeerden worden nadien toch ook advocaat, officier of rechter? Inderdaad was het tot ongeveer tien jaar geleden zo dat ongeveer de helft van de afgestudeerde juristen - zo'n dikke 3000 jaarlijks - in de advocatuur, het notariaat, de rechterlijke macht of het Openbaar Ministerie (OM) aan de slag ging. ${ }^{40}$ En van de circa 15 procent van de afgestudeerden die in andere betrekkingen bij de overheid gingen werken, was ook een groot deel betrokken bij enigerlei vorm van juridische geschilbeslechting. Er is de afgelopen jaren echter wel veel veranderd. Als we kijken naar de cijfers van 2013, dan geeft dat het volgende beeld. ${ }^{41}$ Het totale aantal rechtenstudenten aan de Nederlandse universiteiten (wo) (bachelor en master) is in 2013 redelijk stabiel gebleven ten opzichte van de tien jaar daarvoor. Het aantal bedraagt circa 30.000. Circa 3000 rechtenstudenten studeerden af. Als we wat beter kijken naar die uitstroom, dan zien we dat juristen wat lastiger dan voorheen aan een betaalde baan kunnen komen. Na zes maanden heeft 77 procent van de afgestudeerden een baan. Zo'n jaar of tien geleden lag dat nog ruim boven de 80 procent, zo'n jaar of dertig geleden zelfs enige tijd in de buurt van de 90 procent. ${ }^{42}$ Ongetwijfeld heeft dat te maken met het ongunstige economische tij van de afgelopen jaren, maar er is ook iets aan de hand op de juridische beroepenmarkt. Daar is sprake van een sterke verschraling van het aantal vacatures in traditionele beroepen. Het aantal instromende advocaten loopt bijvoorbeeld zeer sterk terug. In 2007 - voor de financiële en economische crisis - werden nog 1360 stagiairs beëdigd. Dat was een record. Sindsdien gaat het echter bergafwaarts. Met name de laatste paar jaar gaat het hard: in 2014 alleen bedroeg de daling in vergelijking met 2013 zo'n 25 procent, berekende het blad Mr. ${ }^{43}$ Tussen 2009 en 2012 schommelde het aantal stagiairs weliswaar nog rond de 1000, maar in 2013 zette een aanzienlijke daling in. In dat jaar stroomden nog maar 868 advocaat-stagiairs in. In 2014 zette die daling door. Nog maar zo'n 760 instromende stagiairs. In zeven jaar tijd liep de instroom in de advocatuur met zo'n 45 procent terug en het ziet er

40 In 2004 studeren in Nederland in totaal 3217 rechtenstudenten af. 36 procent van die afgestudeerde juristen vindt een baan in de zakelijke dienstverlening, waaronder de advocatuur en het notariaat. Ongeveer 28 procent van de afgestudeerden gaat bij de overheid werken, waaronder ook rechterlijke macht en OM. De overige afgestudeerde juristen starten hun carrière in het onderwijs (4 procent), bij banken (6 procent) of in de industrie (4 procent). Bron: 'De stand van de rechtenstudie 2005'. Zie <www.rechtenstudie.nl/de-stand-van-de-rechtenstudie-2005-0>, laatst geraadpleegd op 16 januari 2015.

41 Cijfers gebaseerd op de WO-monitor 2013.

42 Zie F.W. van Den Berg van Saparoea, Juristen en arbeidsmarkt: onderzoek naar arbeidsmarktontwikkeling voor juristen en de gevolgen daarvan voor de juridische opleiding, SCO-rapport nr. 184, Amsterdam: Stichting Centrum voor Onderwijsonderzoek van de Universiteit van Amsterdam: Stichting Kohnstamm Fonds voor Onderwijsresearch 1988 en Blauw Research, De Imago blauwdruk arbeidsmarkt juristen, Rotterdam 2011.

43 <www.mr-online.nl/juridisch-nieuws/23640-instroom-nieuwe-advocaten-keldert>, 'Instroom nieuwe advocaten keldert', bericht van 22 april 2014, laatst geraadpleegd op 7 februari 2015. 
niet naar uit dat de vacatures op korte termijn aan zullen trekken. ${ }^{44}$ In andere bereiken van het traditionele juridische metier is het al niet veel beter. Nederland kent per eind 2013 circa 2400 rechters bij rechters en hoven, 100 minder dan in $2010 .{ }^{45}$ Wel kwam er meer ondersteunend personeel bij de rechterlijke organisaties. Bij het OM liep het aantal rechterlijke ambtenaren van 827 in 2012 terug naar 770 in 2013. En ook bij de centrale overheid loopt het aantal vacatures terug vanwege de grootschalige hervormingsagenda van de rijksdienst van het kabinetRutte II en de daarmee gepaard gaande taakstellingen. Er is ontegenzeggelijk sprake van een terugloop in de klassieke juridische functies en van digitalisering van traditioneel juridisch werk en overheveling van werk naar de ondersteuning en/of functies waarvoor geen universitaire opleiding nodig is. ${ }^{46}$ Die ontwikkelingen leggen een nieuwe druk op de inrichting van de juridische opleidingen, net als de snelle verwetenschappelijking van de hedendaagse rechtswetenschap dat doet. De judocentrische inrichting van de opleidingen nu sluit veel minder aan op de eisen en vragen van de professionele jurist van weleer. De inrichting van de academische opleiding rechtsgeleerdheid staat daarom ook terecht in het middelpunt van de discussie. Die opleiding zou er meer op gericht moeten zijn kennis en verdiept begrip van het recht bij te brengen, een academische houding, ethiek en vaardigheden. ${ }^{47}$ Trouwens ook in het beroepenveld zelf lijken de behoeften zich te verleggen. In 2014 liet een aantal bestuursvoorzitters van grote Zuidas-advocatenkantoren (De Brauw Blackstone Westbroek, Allen \& Overy, Houthoff Buruma, NautaDutilh en Clifford Chance) in het NRC Handelsblad ${ }^{48}$ weten behoefte te hebben aan een wat ander soort juristen, die naast juridische kennis ook beschikken over basiskennis van psychologie, sociologie, politicologie en economie en over academische vaardigheden als analytisch denken, argumenteren en interpreteren. Zulke juristen hoeven in hun ogen niet langer te beschikken over een bachelordiploma in het recht. Een master in het recht boven op een bachelor psychologie, sociologie, politicologie of economie zou een pre zijn. ${ }^{49}$ Het juridische werk

44 Ook de gehele beroepsgroep van 17.300 advocaten krimpt. In vergelijking met begin 2013 is het aantal advocaten zelfs met 4 procent afgenomen in januari 2015, berekende het blad $M r$. 'De top 50 van de Nederlandse advocatuur', bericht van 27 januari 2015, <www.mr-online.nl/juridischnieuws/25653-de-top-50-van-de-nederlandse-advocatuur >, laatst geraadpleegd op 29 januari 2015.

45 Bron: Factsheet 2014 onder 'De Nederlandse rechtspraak in cijfers', <www.rechtspraak.nl/ Actualiteiten/Persinformatie/Pages/De-Nederlandse-rechtspraak-in-cijfers.aspx>, laatst geraadpleegd op 8 februari 2015. Tellen we de medewerkers er bij op, dan komt het totaal uit op 9995 rechters en medewerkers. Dat is weer wel een toename. Bron: Raad voor de rechtspraak, Jaarverslag rechtspraak over 2010, Den Haag 2011. Overigens behandelen die rechters en medewerkers tegenwoordig tezamen 1,7 miljoen zaken. De productie is tussen 2000 en 2013 met 40 procent toegenomen. Dat geeft aanleiding tot een hoge werkdruk en dilemma's rondom kwaliteit. Zie F.van Dijk, 'De rechter anno 2010', Trema 2003, afl. 2, p. 41-47.

46 G. Hupperetz, 'HBO juristen en de togaberoepen', Ars Aequi 2008, afl. 10, p. 754-756 en G.F.J. Hupperetz, R. Susskind, S. de Rooij \& E. van de Luytgaarden (red.), HBO-Rechten in het werkveld, Nijmegen: Wolf Legal Publishers 2010.

47 Zie Stolker 2014, p. 141 e.v.

48 NRC Handelsblad 17 maart 2014.

49 Ibid. 
verandert, en daarmee ook de opleidingsbehoefte. Dat is een fenomeen dat zich niet beperkt tot Nederland. ${ }^{50}$

\section{Naar een nieuwe universitaire rechtenopleiding?}

Nogmaals het hierboven gaande betoog is geen eenvoudig pleidooi om vakken wetgeving een plaats te geven in de curricula van de opleidingen rechtsgeleerdheid (al zou ik zeker met die uitkomst kunnen leven). Het is vooral een poging om beter te begrijpen. Het laat, denk ik, wel zien waarom we zo weinig wetgevingsonderwijs hebben in rechtenopleidingen, en waarom het zo ontzettend lastig is die rechtenopleiding aan te passen aan de noden van nieuwe tijden. Vooral een cultureel fenomeen. Zolang de juridische opleidingen vooral zijn ingericht om elkaar als juristen te begrijpen en te overtuigen, met de rechter als rolmodel van dé jurist, zal er niet snel iets veranderen. En die verandering is wel nodig, omdat juridisch werk van karakter aan het veranderen is en het beroepenveld om een ander soort academisch opgeleid jurist vraagt. Die moet meer kunnen dan voorheen, lieten de al eerder aangehaalde bestuursvoorzitters van de Zuidas-kantoren vorig jaar weten. Graag zouden ze zien dat er minder accent wordt geplaatst op juridisch technische kennis in de juridische opleidingen ten faveure van een verbreding in multidisciplinaire zin. Ze hebben er zelfs een mal hip acroniem voor: de rechtenopleiding zou zich moeten plooien naar het model van de zogenaamde 'T-shaped-client-loving-lawpreneur'. Een jurist die juridische kennis (de staander in de T) combineert met brede kennis van psychologie, sociologie, politicologie en economie (de ligger in de T). Waarom? Omdat de problemen van alledag te complex zijn om ze louter met kennis van het recht te tackelen. De bestuursvoorzitters roepen op om de juridische opleiding in die zin aan te kunnen passen en het wettelijke kader daaraan aan te passen. ${ }^{51}$ Iets om over na te denken, al hoeft het niet zo te zijn dat de wens van een paar grote kantoren leidend is bij de inrichting van alle rechtenopleidingen. Er is ook een tweede reden om eens kritisch naar de academische rechtenopleiding te kijken. Die zegt nu een academische houding bij te willen brengen (wat dat dan ook precies is), maar heeft ook als ambitie studenten mee te nemen in de laatste stand van de wetenschappelijke inzichten. Dat laatste kan zeker beter, want het juridische onderzoek heeft zich de afgelopen vijftien jaar sterk verwetenschappelijkt - en daar wordt nog niet overal in opgeleid. ${ }^{52} \mathrm{Er}$ is in dat onderzoek meer aandacht voor de context van het recht (internationale dimensie, aandacht voor rechtsvergelijking, effecten die het recht heeft in den brede) en ook een onderkenning dat je die context en betekenissen van het recht niet met vrucht kunt bestuderen met een louter juridische verrekijker. Om

50 Zie R. Susskind, The End of Lawyers? Rethinking the Nature of Legal Services, Oxford: Oxford University Press 2008.

51 E. van de Luytgaarden, 'Juridisch HBO levert al de brede bachelor', Mr. 25 maart 2014.

52 Tot verdriet van enkelen, zoals Cauffman, die menen dat die 'verwetenschappelijking' wellicht leidt tot vervreemding van de rechtswetenschap ten aanzien van de praktijk. C. Cauffman, 'Verwetenschappelijking van het juridisch onderzoek: een garantie voor beter recht?', NTBR 2011/29, p. 211. Het is maar wat je als hoogste doel van de rechtswetenschap ziet natuurlijk. 
via meten tot weten over het recht te komen, is multidisciplinair onderzoek en gebruik van andere dan strikt juridische methoden van belang. Dat betekent nog niet dat iedere juridische onderzoeker twee verschillende academische opleidingen hoeft te hebben gedaan of dat juridische onderzoekers steeds in teams met anders geschoolde academici werken, maar dat we een steeds meer integratieve benadering van het onderzoek kennen. Die kenmerkt zich vooral door meer aandacht voor de werkelijkheid van het recht en aandacht voor - vooral - sociaalwetenschappelijke methoden om die werkelijkheid te leren kennen. ${ }^{53}$ Van den Bos beveelt in zijn oratie Kijken naar het recht uit 2014 aan om die integratieve benadering ook terug te laten keren in het juridische onderwijs. Daarmee sluit hij - wellicht onbedoeld - aan bij de wens van de bestuursvoorzitters van de Zuidaskantoren, die articuleerden welke nieuwe eisen het veranderde juridische werk stelt.

Hoe dat eruit zou kunnen zien? Nee, juristen in de dop hoeven zelf niet psycholoog, econoom of politicoloog te worden, maar het zou wel mooi zijn als ze kunnen begrijpen wat voor soort inzichten die disciplines voortbrengen (of voort kunnen brengen). En dat ze ook kunnen zien of dat soort onderzoek goed is uitgevoerd, of de uitkomst ervan wel of niet klopt. Studenten opleiden tot werkelijke academische professionals, dus. Want als je wilt begrijpen wat het recht is, wat het betekent in de samenleving, en wat je als professional daarmee zou moeten kunnen, is het, denk ik, verstandiger vooral te kijken naar de context en het effect van recht, rechtsvorming en rechtspleging. In de curricula zou veel meer vanuit de theorie van het recht (wat is het doel van het recht, wat drukt het uit, maar ook wat kan/moet het bewerkstelligen?) moeten worden gekeken naar de realiteit en context van het recht. Wat betekent het tegenwoordig? Welke invloed heeft het op onze samenleving, op onze markten? In welke mate draagt recht al dan niet bij aan welzijn, welvaart, economische groei, vertrouwen en sociale cohesie? Waarom leven we het recht na, en waarom soms niet? Wat betekent het voor de aanvaardbaarheid van overheidshandelen? Aandacht voor de rollen en contexten van het recht is wezenlijk. ${ }^{54}$

Ik heb eigenlijk nooit helemaal begrepen waarom de rechtenstudie niet is ingericht volgens het basisschema, wetgever en recht, bestuur en recht (en dat is wat anders dan bestuursrecht) en rechter en recht. En dat we studenten volgens verschillende benaderingen (niet alleen de juridische) vragen zich daarin te verdiepen, met gevoel voor context. Daar lijken me het wetenschappelijke aanbod en de zich snel ontwikkelende vraag weer bijeen te komen. En dat kan, teken ik erbij aan, eenvoudig met behoud van civiel effect.

54 Marc Loth stelt dat het verrijkend is om de studie van het recht in de loop van de opleiding te verbreden tot de context waarin het toepassing vindt, zie Loth 2012. 